Gut, 1961, 2, 163

\title{
Gastric acid secretion and mucosal appearances in Addison's disease and hypopituitarism
}

\author{
A. W. M. SMITH, I. W. DELAMORE, AND A. WYNN WILliamS \\ From the Departments of Therapeutics, Medicine, and Pathology, University of \\ Edinburgh, and the Royal Infirmary, Edinburgh
}

SYNOPSIS Studies of gastric acid secretion and mucosal appearances have been made in a group of 14 patients suffering from hypopituitarism. Achlorhydria was found in six of the patients suffering from Addison's disease but in only one patient suffering from hypopituitarism. In both groups the mean gastric secretion of hydrochloric acid was considerably lower than in a group of control subjects and replacement therapy with cortisone and DOCA in Addison's disease and cortisone and thyroid extract in hypopituitarism failed to restore gastric function to normal. A constant correlation was not found between gastric acid secretion and mucosal appearances.

Since Grawitz (1907) reported that the gastric acid secretion in Addison's disease was depressed various other workers have found achlorhydria in approximately half of such patients (Rowntree and Snell, 1931; Sorkin, 1949; Soffer, 1956). Card and Sircus (1958) pointed out, however, that no consistent changes in gastric acid secretion had been observed in Addison's disease using the augmented histamine secretion test (Kay, 1953). Hypochlorhydria or achlorhydria is also said to be a feature of hypopituitarism (Escamilla and Lisser, 1942; Soffer, 1956), and Card and Sircus (1958) have reported one patient suffering from hypopituitarism who had achlorhydria in response to the maximal histamine secretion test and another in whom the output of hydrochloric acid did not rise after histamine stimulation.

Feyrter and Klima (1952) noted that achlorhydria in Addison's disease may be associated with extensive gastric atrophy but apart from this observation very few studies have been made of the histology of the gastric mucosa in this disease or in hypopituitarism. Animal investigations, however, suggest that in such conditions the gastric mucous membrane undergoes atrophy and that there may be a diminution in the number of parietal cells. Haeger, Jacobsohn, and Kahlson (1953) found atrophy of the gastric mucosa in cats after removal of either the pituitary or the adrenals and concluded that the maintenance of the mucosa was a function of the pituitary gland and that this was dependent at least partially on the adrenal glands. Other workers state that in adrenalectomized (Baker and Bridgman, 1954) or hypophysectomized (Baker and Abrams,
1954) rats the zymogenic cells of the gastric mucosa are reduced in size and degranulated but there is relatively little structural change in the parietal cells. Friedman (1953), on the other hand, found that the parietal cell count was reduced by $50 \%$ in the gastric mucosa of rats that had been subjected to hypophysectomy.

Card and Marks (1960), using the modified augmented histamine secretion test (Kay, 1953; Card and Sircus, 1958), have shown that the output of hydrochloric acid by the stomach can be related to the parietal cell mass. Most of the previous reports on gastric secretion in Addison's disease and hypopituitarism have been based on less reliable and less exact methods. In view of this and because of the paucity of reports on gastric histology in these patients, it was decided to reinvestigate the question of gastric secretion by means of the augmented histamine secretion test and to correlate the results with the appearances of the gastric mucosa obtained by peroral biopsy.

\section{MATERIALS AND METHODS}

Fourteen patients suffering from Addison's disease, with an average age of 43 years, and 10 patients suffering from hypopituitarism with an average age of 52 years, were included in the study and they represented a successive series of patients who presented for admission to hospital or review at the endocrine clinic. These patients all had the classical features of Addison's disease or hypopituitarism and the diagnosis was confirmed by the usual laboratory investigations which included, when necessary, the measurement of urinary ketosteroids and 163 
ketogenic steroids, a glucose tolerance test, an insulin sensitivity test, radioactive iodine studies, and an A.C.T.H. stimulation test. In the 14 Addisonian patients the disease was considered to be of tuberculous origin in six (Table I, Cases 3, 4, 5, 7, 9, and 11) and of the idiopathic variety in the remaining eight. Three were untreated or had received treatment for only a few days; the remaining 11 had received replacement therapy in the form of cortisone for periods varying from four to seven years and all except Case 6 (Table I) had received DOCA in addition, often for much longer periods.

All of the patients suffering from hypopituitarism were women. The disease followed surgical removal of a chromophobe adenoma from the pituitary in three (Table II, Cases 2, 3, and 6) but was considered to be consequent upon postpartum haemorrhage in five of the remaining seven patients (Cases $1,4,5,7$, and 10). In two (Cases 8 and 9), there was no obvious cause. Three of the 10 patients were untreated at the time of investigation but the remaining seven had received cortisone for periods varying from six months to eight years, supplemented by thyroid extract in most cases.

In each case the modified histamine secretion test (Kay, 1953; Card and Sircus, 1958) was carried out. After histamine stimulaticn the gastric juice was collected by continuous suction for the next hour and achlorhydria was considered to be present when the $\mathrm{pH}$ did not fall below 6. Gastric biopsies were performed with a Wood's gastric biopsy tube or the biopsy capsule of Crosby and Kugler (1957). The tip of the instrument was positioned in the body of the stomach under fluoroscopic control in every instance except one (Table II, Case 10).

\section{RESULTS}

GASTRIC SECRETION IN ADDISON'S DISEASE The relevant clinical and laboratory data are shown in Table I. Achlorhydria was found in five of the 14 patients and in one further patient (Case 5) no acid was found by titration but the $p \mathrm{H}$ fell to $5 \cdot 5$. The average secretion of hydrochloric acid in the post- histamine hour was $5 \mathrm{mEq}$. for the whole group (5.9 mEq. for men and $3.5 \mathrm{mEq}$. for women). The treated group had an average output of $3.1 \mathrm{mEq}$. of hydrochloric acid in the post-histamine hour. The untreated group contained only three representatives, but it is of interest to note that it included the patient with the highest secretion of all.

GASTRIC SECRETION IN HYPOPITUITARISM Details of the cases are shown in Table II. There was only one instance of complete achlorhydria. This patient was re-examined after six months' treatment with cortisone and achlorhydria was still present. The average output of hydrochloric acid in the post-histamine hour for the whole group was $6.6 \mathrm{mEq}$.

The mean values for gastric acid secretion in the group of patients suffering from Addison's disease and the group suffering from hypopituitarism are shown in Table III. It will be seen that in both groups the figures are considerably lower than those obtained from control subjects (Card and Sircus, 1960). In neither group was there any obvious correlation between the duration of the disease or the duration of treatment and the changes in acid secretion.

GASTRIC BIOPSIES Specimens were obtained from 12 patients with Addison's disease and from nine patients with hypopituitarism. They were fixed in corrosive-formol and stained with haematoxylin and eosin, also by Zimmermann's method for the differential staining of gastric mucosa, as modified by Marks and Drysdale (1957).

Addison's disease Eight of the 12 patients had abnormal gastric mucosa. In one patient (Case 1) there was glandular atrophy, viz., complete absence of body glands and isolated parietal cells, but no

TABLE I

ADDISON'S DISEASE

\begin{tabular}{|c|c|c|c|c|c|c|c|}
\hline \multirow[t]{2}{*}{ Case } & \multirow[t]{2}{*}{ Age } & \multirow[t]{2}{*}{ Sex } & \multirow{2}{*}{$\begin{array}{l}\text { Duration of } \\
\text { Disease } \\
\text { (years) }\end{array}$} & \multicolumn{2}{|c|}{$\begin{array}{l}\text { Duration of Treatment } \\
\text { (years) }\end{array}$} & \multirow{2}{*}{$\begin{array}{l}\text { Maximal Histamine } \\
\text { Response (mEq. in } \\
\text { post-histamine } \\
\text { hour) }\end{array}$} & \multirow[t]{2}{*}{ Gastric Biopsy Findings } \\
\hline & & & & Cortisone & $D O C A$ & & \\
\hline 1 & 30 & $\mathbf{M}$ & $14 \frac{1}{2}$ & 7 & 14 & $\mathbf{0}$ & Atrophy \\
\hline 2 & 60 & $\mathbf{M}$ & 9 & $6 \frac{1}{2}$ & 8 & 0.2 & Chronic gastritis and partial glandular atrophy \\
\hline 3 & 60 & $\mathbf{M}$ & $12 \frac{1}{2}$ & $7^{2}$ & 12 & $\mathbf{0}$ & Normal \\
\hline 4 & 38 & $\mathbf{M}$ & $10 \frac{1}{2}$ & 7 & 10 & $12 \cdot 2$ & Not done \\
\hline 5 & 40 & $\mathbf{M}$ & $10 \frac{1}{2}$ & 7 & 10 & $0(p H 5 \cdot 5)$ & Chronic gastritis and partial glandular atrophy \\
\hline 6 & 53 & $\mathbf{M}$ & $4 \frac{1}{2}$ & 4 & 0 & 0 & Chronic atrophic gastritis \\
\hline 7 & 38 & $\mathbf{M}$ & 5 & 4 & 4 & $12 \cdot 8$ & Chronic gastritis and partial glandular atrophy \\
\hline 8 & 17 & $\mathbf{M}$ & $\mathbf{0}$ & $\mathbf{0}$ & $\mathbf{0}$ & $27 \cdot 5$ & Normal \\
\hline 9 & 38 & $\mathbf{M}$ & $\frac{1}{2}$ & $\mathbf{0}$ & $\mathbf{0}$ & 0.4 & Chronic gastritis and partial glandular atrophy \\
\hline 10 & 46 & $\mathbf{F}$ & 15 & 5 & 13 & 0 & Chronic gastritis and partial glandular atrophy \\
\hline 11 & 41 & $\mathbf{F}$ & 16 & $5 \frac{1}{2}$ & 16 & $5 \cdot 3$ & Normal \\
\hline 12 & 57 & $\mathbf{F}$ & 8 & 7 & 7 & $\mathbf{0}$ & Chronic atrophic gastritis \\
\hline 13 & 42 & $\mathbf{F}$ & 7 & 4 & $6 \frac{1}{2}$ & $3 \cdot 5$ & Not done \\
\hline 14 & 40 & $\mathbf{F}$ & 4 & $\mathbf{0}$ & $\mathbf{0}$ & $8 \cdot 7$ & Normal \\
\hline
\end{tabular}


TABLE II

HYPOPITUITARISM

\begin{tabular}{|c|c|c|c|c|c|c|c|}
\hline \multirow[t]{2}{*}{ Case } & \multirow[t]{2}{*}{ Age } & \multirow[t]{2}{*}{$\operatorname{Sex}$} & \multirow{2}{*}{$\begin{array}{l}\text { Duration } \\
\text { of Disease } \\
\text { (years) }\end{array}$} & \multicolumn{2}{|c|}{$\begin{array}{l}\text { Duration of Treatment } \\
\text { (years) }\end{array}$} & \multirow{2}{*}{$\begin{array}{l}\text { Maximal Histamine Response } \\
\text { (mEq. HCl in post-histamine } \\
\text { hour) }\end{array}$} & \multirow[t]{2}{*}{ Gastric Biopsy } \\
\hline & & & & Cortisone & Thyroid & & \\
\hline 1 & 55 & $\mathbf{F}$ & 23 & 5 & 7 & $6 \cdot 1$ & Normal \\
\hline 2 & 56 & $\mathbf{F}$ & 31 & 3 & 0 & 6.2 & Failed \\
\hline 3 & 42 & $\mathbf{F}$ & $13^{2}$ & 3 & 3 & 9 & Normal \\
\hline 4 & 47 & $\mathbf{F}$ & 16 & 4 & 2 & $3 \cdot 7$ & Atrophy \\
\hline 5 & 50 & $\mathbf{F}$ & 22 & 7 & $6 \frac{1}{2}$ & $14 \cdot 2$ & Normal \\
\hline 6 & 63 & $\mathbf{F}$ & 11 & 8 & $8^{2}$ & $14 \cdot 4$ & Normal \\
\hline 7 & 42 & $\mathbf{F}$. & $19 \frac{1}{2}$ & 5 & 5 & 1.8 & Normal \\
\hline 8 & 62 & $\mathbf{F}$ & $20^{2}$ & 0 & 0 & 0 & Partial atrophy \\
\hline & & & & $\frac{1}{2}$ & 0 & 0 & Not repeated \\
\hline 9 & 53 & $\mathbf{F}$ & 24 & 0 & 0 & $2 \cdot 9$ & Normal \\
\hline 10 & 45 & $\mathbf{F}$ & 21 & 0 & 0 & $7 \cdot 5$ & Atrophy \\
\hline
\end{tabular}

TABLE III

ACID SECRETORY RESPONSE IN PATIENTS SUFFERING FROM ADDISON'S DISEASE OR HYPOPITUITARISM COMPARED WITH NORMAL SUBJECTS

\begin{tabular}{|c|c|c|c|c|c|c|c|c|}
\hline & \multirow{3}{*}{$\begin{array}{l}\text { Mean } \\
\text { Age }\end{array}$} & \multicolumn{3}{|l|}{ Males } & \multirow{3}{*}{$\begin{array}{l}\text { Mean } \\
\text { Age }\end{array}$} & \multicolumn{3}{|l|}{ Females } \\
\hline & & \multirow[t]{2}{*}{$\begin{array}{l}\text { No. of } \\
\text { Patients }\end{array}$} & \multicolumn{2}{|c|}{$\begin{array}{l}\text { Maximal Histamine } \\
\text { Response (mEq. HCl in } \\
\text { post-histamine hour) }\end{array}$} & & \multirow[t]{2}{*}{$\begin{array}{l}\text { No. of } \\
\text { Patients }\end{array}$} & \multicolumn{2}{|c|}{$\begin{array}{l}\text { Maximal Histamine } \\
\text { Response (mEq. } \mathrm{HCl} \text { in } \\
\text { post-histamine hour) }\end{array}$} \\
\hline & & & Range & Mean & & & Range & Mean \\
\hline $\begin{array}{l}\text { Addison's disease } \\
\text { Hypopituitarism } \\
\text { Normals (Card and Sircus, 1960) }\end{array}$ & $\underline{42}$ & $\frac{9}{29}$ & $\begin{array}{l}0-27 \cdot 5 \\
10 \cdot 1-41 \cdot 5\end{array}$ & $\frac{5 \cdot 9}{22 \cdot 65}$ & $\begin{array}{l}45 \\
52 \\
-\end{array}$ & $\begin{array}{r}5 \\
10 \\
28\end{array}$ & $\begin{array}{l}0-8 \cdot 7 \\
0-14 \cdot 4 \\
6 \cdot 2-34 \cdot 6\end{array}$ & $\begin{array}{r}3 \cdot 5 \\
6 \cdot 6 \\
17 \cdot 2\end{array}$ \\
\hline
\end{tabular}

TABLE IV

STATISTICAL ANALYSIS OF ACID SECRETORY RESPONSE

\begin{tabular}{lrrrrrr} 
& \multicolumn{2}{l}{ Males } & & \multicolumn{2}{l}{ Females } \\
\cline { 2 - 3 } & No. & Mean $\pm S D$ & & No. & Mean $\pm S D$ \\
\hline Normals & 29 & $24.11 \pm 1.53$ & & 28 & $17.20 \pm 1.36$ \\
Addison's disease & 9 & $5.90 \pm 3.24$ & & 5 & $3.30 \pm 1.65$ \\
Hypopituitarism & & & & 11 & $5.98 \pm 1.52$
\end{tabular}

TABLE V

STATISTICAL ANALYSIS OF ACID SECRETORY RESPONSE

$\begin{array}{ll}\text { Difference } & \begin{array}{l}\text { Degrees } \quad t \quad p \\ \text { of } \\ \text { Freedom }\end{array}\end{array}$

\begin{tabular}{lllll}
\hline $\begin{array}{l}\text { Normals-Addison's disease: } \\
\text { Males }\end{array}$ & 18.21 & 36 & 5.56 & $<.001$ \\
Females & 13.70 & 31 & 4.11 & $<.001$ \\
& & & & \\
$\begin{array}{l}\text { Normals-hypopituitarism: } \\
\text { Females }\end{array}$ & 11.22 & 37 & 4.70 & $<.001$
\end{tabular}

inflammatory signs, while in two others (Cases 6 and 12) the appearances were those of chronic atrophic gastritis, viz., chronic inflammatory signs of mild to moderate degree in addition to glandular atrophy. In five patients (Cases 2, 5, 7, 9, and 10) chronic gastritis was present with only slight glandular atrophy; the mucosa in these patients contained body glands and parietal cells were generally conspicuous; the inflammatory signs were mild to moderate except in one patient where they were fairly severe; in two patients (Cases 2 and 4 ), mitotic figures were conspicuous in the necks of the glands, a feature indicating active regeneration. Intestinal metaplasia was present in only one of the eight patients (Case 6) with an abnormal gastric mucosa. In the remaining four patients, the gastric mucosa had a normal histological structure. Body glands were numerous and regularly arranged and no inflammatory signs were present. It is of considerable interest, however, that one of these patients (Case 3) had achlorhydria.

Hypopituitarism In three patients, the gastric mucosa was abnormal while in the other six patients it was normal.

In two patients (Cases 4 and 10) the histological appearances were those of complete gastric atrophy, the mucosa being thin and containing only glands of pyloric type; parietal cells were absent and there were no inflammatory signs. Intestinal metaplasia was also absent. In another patient (Case 8), there was partial gastric atrophy. 


\section{DISCUSSION}

This study has confirmed the previous observations of diminished gastric secretion of hydrochloric acid in Addison's disease and hypopituitarism, and it has shown that the high incidence of achlorhydria is frequently associated with atrophic and inflammatory changes in the gastric mucosa, particularly the former. In most cases there was good correlation between the degree of pathological change and the level of acid secretion but there were some exceptions, and it is of particular interest that in one case of Addison's disease (Table 1, Case 3) complete achlorhydria was associated with a normal gastric biopsy. This finding is not entirely unexpected since it is reasonable to assume that gastric secretion is governed not only by size of the parietal cell mass, but also by the reactivity of the parietal cells present and the level of circulating blood hormones.

These functional and structural changes were found more commonly in Addison's disease than in hypopituitarism and this may be a reflection of the relatively greater depression of adrenal function which usually occurs in the former condition. One case only of achlorhydria in hypopituitarism was noted and this persisted after six months' therapy with cortisone. It is, of course, possible that a higher percentage of patients suffering from hypopituitarism in this present investigation would have been achlorhydric had all 10 patients been untreated, but it is significant in this respect that the mean gastric secretion of the whole group was considerably lower than that for control subjects. Spence and Witts (1939) and Kyle (1955), however, have each described a case of hypopituitarism with achlorhydria and gastric atrophy, as judged through a gastroscope in which there was a response to treatment. The first patient was treated with an extract of pig pituitary gland and human urine of pregnancy and the second with cortisone and thyroid extract; in both cases the gastric secretion and gastroscopic appearances returned to normal.

Despite therapy with cortisone for four years or more, six of the 14 patients with Addison's disease in the present series remained achlorhydric. Soffer (1956) related the presence of achlorhydria or hypochlorhydria in Addison's disease to the clinical status of the patient and concluded that the disturbance was one of body fluids and electrolytes which was reversible. It has been shown, moreover, that cortisone administration to normal individuals increases greatly the secretion of hydrochloric acid (Gray, Benson, Spiro, and Reifenstein, 1951); Kirsner, Klotz, and Palmer, 1952) and that there is a diminished excretion of uropepsin in Addison's disease which returns to normal or higher than normal with glucocorticoid replacement therapy (Gray, 1959). Stempien and Dagradi (1954) reported one patient with adrenal insufficiency and normal gastroscopic appearances whose gastric acid secretion was markedly impaired on histamine stimulation which rapidly improved following treatment with cortisone, and Welbourn and Code (1953) demonstrated that prior adrenalectomy of pylorus-ligated rats produced a significant decrease of gastric acid secretion which was restored to normal with cortisone therapy. Such reports have led to the formulation of the 'permissive' theory by Krakauer, Ramsey, and Gray (1955) which suggests that the adrenal corticoid hormones play a permissive role so that in the presence of excess adrenal hormones the stomach or duodenum may be sensitized to respond by secretory hyperactivity and/or ulceration to stimuli which would normally be innocuous.

The failure of cortisone to restore the acid secretion in six of our patients with Addison's disease and one with hypopituitarism may indicate that in humans some factor or factors other than DOCA in Addison's disease and thyroid extract in hypopituitarism is required for full replacement therapy or that the gastric mucosa had undergone irreversible change before treatment began. It should be noted, however, that in Cases 6 and 12 (Table I), where treatment was begun within a matter of months after the development of symptoms, there was no return of gastric acid secretion on maximal histamine stimulation.

We wish to thank Sir Derrick Dunlop for permission to investigate these patients, and we are very grateful to Dr. W. I. Card and Di. W. Sircus for their generous help in supplying figures of normal gastric secretion levels. Dr. Barnet Woolf gave generous help with the statistical analysis.

\section{REFERENCES}

Baker. B. L., and Abrams, G. D. (1954). Effect of hypophysectomy on the cytology of the fundic glands of the stomach and on the secretion of pepsin. Amer. J. Physiol., 177, 409-412.

and Bridgman, R. M. (1954). The histology of the gastrointestinal mucosa (rat) after adrenalectomy or administration of adreno-cortical hormones. Amer. J. Anat., 94, 363-387.

Card, W. I., and Marks, I. N. (1960). The relationship between the acid output of the stomach following "maximal" histamine stimulation and the parietal cell mass. Clin. Sci., 19, 147163.

- , and Sircus, W. (1958). In Modern Trends in Gastro-enterology, (2nd Series), p. 177. Editor, F. Avery Jones. Butterworth, London.

,$--(1960)$. Personal communication.

Crosby, W. H., and Kugler, H. W. (1957). Intraluminal biopsy of the small intestine: the intestinal biopsy capsule. Amer. J. dig. Dis., n.s. 2, 236-241.

Escamilla, R. F., and Lisser, H. (1942). Simmonds' disease: a clinical study with review of the literature; differentiation from anorexia nervosa by statistical analysis of 595 cases, 101 of which were proved pathologically. Ibid, 2, 65-96. 
Feyrter, F, and Klima, R. (1952). Úber die Magenveränderungen bei der Addisonschen Krankheit. Dtsch. med. Wschr., 77, 1173-1175.

Friedman, M. H. F. (1953). The response of different regions of the gastrointestinal tract to normal and abnormal stimuli (influence of feeding inert bulk material and of hypophysectomy). J. nat. Cancer Inst., 13, 1035-1038.

Grawitz, E. (1907). Ưber Heilung des Morbus Addisonii nebst Bemerkungen über die Pathogenese dieser Krankheit. Dtsch. med. Wschr., 2, 1084-1086.

Gray, S. J. (1959). Present status of endocrine influences upon the stomach and their relationship to peptic ulcer disease. Gastroenterology, 37, 412-420.

_- Benson, J. A., Jr., Spiro, H. M., and Reifenstein, R. W. (1951). Effects of ACTH and cortisone upon the stomach: its significance in the normal and in peptic ulcer. Ibid, 19, 658673.

Haeger, K., Jacobsohn, D., and Kahlson, G. (1953). Atrophy of the gastrointestinal mucosa following hypophysectomy or adrenalectomy Acta physiol. scand., 30, Suppl. 111, pp. 161-169.

Kay, A. W. (1953). Effect of large doses of histamine on gastric secretion of $\mathrm{HCl}$ : an augmented histamine test. Brit. med. J., 2, 77-80.

Kirsner, J. B., Klotz, A. P., and Palmer, W. L. (1952). Unfavorable course of gastric ulcer during administration of ACTH and cortisone. Gastroenterology, 20, 27-29.
Krakauer ,L. J., Ramsey, C. G., and Gray, S. J. (1955). The relationship of gastric activity and adrenocortical function: a correlative study. Clin. Res. Proc., 3, 131.

Kyle, J. (1955). Gastric secretion in Simmonds's disease. Lancet, 2, 724-725.

Marañon, G., Sala, P., and Arguelles, G. (1934). Digestive symptoms in chronic suprarenal insufficiency (Addison's disease). Endocrinology, 18, 497-504.

Marks, I. N., and Drysdale, K. M. (1957). A modification of Zimmermann's method for differential staining of gastric mucosa. Stain Technol, $32,48$.

Rowntree, L. G., and Snell, A. M. (1931). A Clinical Study of Addison's Disease. Saunders, Philadelphia and London.

Soffer, L. J. (1956). Diseases of the Endocrine Glands, 2nd ed. Lea and Febiger, Philadelphia.

Sorkin, S. Z. (1949). Addison's disease. Medicine (Baltimore), 28, 371-425.

Spence, A. W., and Witts, L. J. (1939). Substitution therapy in hypopituitarism. Quart. J. Med., 32, (n.s. 8), 69-77.

Stempien, S. J., and Dagradi, A. (1954). The histamine response of the gastric mucosa in a patient with adrenal insufficiency: effect of cortisone administration. Gastroenterology, 27, 358-362.

Welbourn, R. B., and Code, C. F. (1953). Effects of cortisone and of adrenalectomy on secretion of gastric acid and on occurrence of gastric ulceration in the pylorus-ligated rat. Ibid, 23, 356-362. 